\title{
Reference gene selection for qRT-PCR assays in Stellera chamaejasme subjected to abiotic stresses and hormone treatments based on transcriptome datasets
}

\author{
Xin Liu ${ }^{1,2}$, Huirui Guan ${ }^{1,2}$, Min Song ${ }^{1,2}$, Yanping Fu ${ }^{1,2}$, Xiaomin Han ${ }^{1,2}$, Meng Lei ${ }^{1,2}$, Jingyu Ren ${ }^{1,2}$, Bin \\ Guo $^{1,2}$, Wei He ${ }^{1,2}$, Yahui Wei ${ }^{\text {Corresp. }{ }^{1,2}}$ \\ ${ }^{1}$ College of Life Science, Northwest University, Xi'an, Shaanxi, China \\ 2 Key Laboratory of Resource Biology and Biotechnology in Western China, Northwest University, Xi'an, Shaanxi, China \\ Corresponding Author: Yahui Wei \\ Email address: weiyahui@nwu.edu.cn
}

Background. Stellera chamaejasme Linn, an important poisonous plant of the China grassland, is toxic to humans and livestock. The rapid expansion of $S$. chamaejasme has greatly damaged the grassland ecology and, consequently, seriously endangered the development of animal husbandry. To draft efficient prevention and control measures, it has become more urgent to carry out research on its adaptive and expansion mechanisms in different unfavorable habitats at the genetic level. qRT-PCR is a widely used technique for studying gene expression at the transcript level; however, qRT-PCR requires reference genes (RGs) as endogenous controls for data normalization and only through appropriate RG selection and qRT-PCR can we guarantee the reliability and robustness of expression studies and RNA-seq data analysis. Unfortunately, little research on the selection of RGs for gene expression data normalization in S. chamaejasme has been reported. Method. In this study, 10 candidate RGs namely, 18S, 60S, CYP, GAPCP1, GAPDH2, EF1B, MDH, SAND, TUA1, and TUA6, were singled out from the transcriptome database of $S$. chamaejasme, and their expression stability under three abiotic stresses (drought, cold, and salt) and three hormone treatments (ABA, GA, and ETH) were estimated with the programs geNorm, NormFinder, and BestKeeper. Result. Our results showed that GAPCP1 and EF1B were the best combination for the three abiotic stresses, whereas TUA6 and SAND, TUA1 and CYP, GAPDH2 and 605 were the best choices for ABA, GA and ETH treatment, respectively. Moreover, GAPCP1 and 60S were assessed to be the best combination for all samples, and $18 S$ was the least stable RG for use as an internal control in all of the experimental subsets. The expression patterns of two target genes (P5CS2 and GI) further verified that the RGs that we selected were suitable for gene expression normalization. Discussion. This work is the first attempt to comprehensively estimate the stability of RGs in S. chamaejasme. Our results provide suitable RGs for high-precision normalization in qRT- 
PCR analysis, thereby making it more convenient to analyze gene expression under these experimental conditions. 


\section{Reference gene selection for qRT-PCR assays in Stellera}

2 chamaejasme subjected to abiotic stresses and hormone

3 treatments based on transcriptome datasets

4 Xin Liu, Huirui Guan, Min Song, Yanping Fu, Xiaomin Han, Meng Lei, Jingyu Ren, Bin Guo, Wei He, Yahui

5 Wei* $^{*}$

6 College of Life Science, Northwest University, Xi'an, Shaanxi, China

7 Key Laboratory of Resource Biology and Biotechnology in Western China, Northwest University, Xi'an,

8 shaanxi, China

9 Corresponding Author:

10 Yahui Wei

11 Northwest University, No.229, TaiBai NorthRoad, Xi'an, shaanxi, 710069, China

12 Email address: weiyahui@nwu.edu.cn 


\section{ABSTRACT}

Background. Stellera chamaejasme Linn, an important poisonous plant of the China grassland, is toxic to humans and livestock. The rapid expansion of $S$. chamaejasme has greatly damaged the grassland ecology and, consequently, seriously endangered the development of animal husbandry. To draft efficient prevention and control measures, it has become more urgent to carry out research on its adaptive and expansion mechanisms in different unfavorable habitats at the genetic level. qRT-PCR is a widely used technique for studying gene expression at the transcript level; however, qRT-PCR requires reference genes (RGs) as endogenous controls for data normalization and only through appropriate RG selection and qRT-PCR can we guarantee the reliability and robustness of expression studies and RNA-seq data analysis. Unfortunately, little research on the selection of RGs for gene expression data normalization in S. chamaejasme has been reported.

Method. In this study, 10 candidate RGs namely, $18 S, 60 S, C Y P, G A P C P 1, G A P D H 2, E F 1 B$, $M D H, S A N D, T U A 1$, and TUA6, were singled out from the transcriptome database of $S$. chamaejasme, and their expression stability under three abiotic stresses (drought, cold, and salt) and three hormone treatments (ABA, GA, and ETH) were estimated with the programs geNorm, NormFinder, and BestKeeper.

Result. Our results showed that $G A P C P 1$ and $E F 1 B$ were the best combination for the three abiotic stresses, whereas TUA6 and SAND, TUA1 and $C Y P, G A P D H 2$ and $60 S$ were the best choices for ABA, GA and ETH treatment, respectively. Moreover, GAPCP1 and $60 S$ were assessed to be the best combination for all samples, and $18 S$ was the least stable RG for use as an internal control in all of the experimental subsets. The expression patterns of two target genes (P5CS2 and GI) further verified that the RGs that we selected were suitable for gene expression normalization.

Discussion. This work is the first attempt to comprehensively estimate the stability of RGs in $S$. chamaejasme. Our results provide suitable RGs for high-precision normalization in qRT-PCR analysis, thereby making it more convenient to analyze gene expression under these experimental conditions.

\section{INTRODUCTION}

Stellera chamaejasme Linn (Thymelaeaceae), a perennial herb and dominant plant of grassland desertification, is native to the northern and southwestern regions in China (Tseng, 1999; Sepulveda-Jimenez et al., 2005). The whole plant is toxic, and its main toxic component is isochamaejasmin, which can poison and kill cattle, sheep and other livestock (Shi \& Wei, 2016). The rapid spread of $S$. chamaejasme speeds up the process of grassland desertification and also poisons a large number of livestock in pasturing areas, causing great damage and loss to the local grassland ecology and livestock husbandry (Shi \& Wei, 2016). Thus, it is of fundamental importance to elucidate the mechanisms of the rapid spread and stress adaptation of $S$. chamaejasme. However, limited genome sequence information is available, which greatly hinders the study of stress functional genes, ultimately resulting in a slow advancement of prevention and control measures. For the above reasons, our group established local transcriptome data for $S$. chamaejasme seedlings at five different time points $(300 \mathrm{mM} \mathrm{NaCl}$ 
54

55

56

57

58

59

60

61

62

63

64

65

66

67

68

69

70

71

72

73

74

75

76

77

78

79

80

81

82

83

84

85

86

87

88

89

90

91

92

93

94

95

96

97

treatment for $0 \mathrm{~h}, 3 \mathrm{~h}, 12 \mathrm{~h}, 24 \mathrm{~h}$, and $72 \mathrm{~h}$; three biological replicates) using the Illumina HiSeq 4000 sequencing platform. After transcriptome sequencing and data analysis, fragments per kilobase of exons per million fragments mapped (FPKM) converted from RSEM (RNA-Seq by Expectation Maximization) were used to estimate unigene expression, which in some cases led to a few false-positive results.

qRT-PCR is one of the most widely applied technologies to detect the expression levels of selected genes in many different samples (Huggett et al., 2005) because of its relatively accurate quantification, simplicity, specificity, high sensitivity and high throughput capacity (Qi et al., 2016; Wang et al., 2016a). In the relative quantitative method of qRT-PCR data processing, the choice of internal genes is particularly important, and small changes in reference gene (RG) stability will significantly influence the accuracy of the relative expression of target genes (Dheda et al., 2005). Generally speaking, an ideal RG should be an endogenous gene that does change in any of the tested tissues or under any of the experimental conditions (Derveaux, Vandesompele \& Hellemans, 2010; Li et al., 2016a; Wang et al., 2016b). In cells, some endogenous housekeeper genes with consistent relative expression are often used as reference genes (Taylor et al., 2016).

Housekeeping genes (HKGs) generally refer to a class of highly conserved genes that have basic functionality in biochemistry metabolism in organisms (Fiume \& Fletcher, 2012) and are normally expressed at relatively constant rates across different tissues (Warrington et al., 2000; Paolacci et al., 2009). However, several studies have found that the expression levels of HKGs vary to different degrees based on tissues, developmental stages, or experimental conditions (Thellin et al., 1999; Nicot et al., 2005; Wu et al., 2016). Therefore, it is necessary to select stably expressed HKGs as RGs before they are used to normalize target gene expression by qRTPCR (Guenin et al., 2009; Gong et al., 2016). Up to date, many HKGs, such as $18 \mathrm{~S}$ ribosomal RNA (18S rRNA), 28S ribosomal RNA (28S rRNA), $\beta$-actin $(A C T)$, elongation factor 1-alpha (EF1A), glyceraldehyde-3-phosphate dehydrogenase $(G A P D H), \alpha$ tubulin $(T U A), \beta$ tubulin $(T U B)$, polyubiquitin $(U B Q)$, cyclophilin $(C Y P)$, SAND protein family $(S A N D)$, malate dehydrogenase $(M D H)$, glyceraledehyde-3-phosphate dehydrogenase of plastid 1 (GAPCPI) and so on, have been used to conducted studies for evaluating their stability under different experimental conditions (Demidenko, Logacheva \& Penin, 2011; Chen et al., 2015; Cao, Wang \& Lan, 2016; Ferraz Dos Santos et al., 2016; Wang et al., 2017).

As of now, there is no available internal control gene for qRT-PCR data normalization in $S$. chamaejasme, so we were unable to verify transcriptome sequencing results, analyze the expression patterns of salt or stress-related genes, or further clarify its spread mechanism. To solve this problem, in our study, we selected 10 candidate RGs based on the local salt $S$. chamaejasme transcriptome database and then determined their expression profiles in five different stages under various abiotic stresses (drought, salt, and cold) and with three hormone treatments (abscisic acid, ABA; gibberellin, GA; ethephon, ETH) by qRT-PCR and further evaluated their expression stabilities using three popular software packages: geNorm (Vandesompele et al., 2002), NormFinder (Andersen, Jensen \& Orntoft, 2004) and BestKeeper (Pfaffl et al., 2004). The 10 candidate genes were $18 S, 60 S, C Y P, E F 1 B, G A P C P 1$, GAPDH2, $M D H, S A N D, T U A 1$, and TUA6. Two target genes, Delta 1-pyrroline-5-carboxylate synthetase 2 (P5CS2), which encodes a crucial enzyme in the proline synthesis pathway under stress conditions by activating glutamate 5-kinase and glutamate-5-semialdehyde dehydrogenase 
98 (Strizhov et al., 1997), and GIGANTEA ( $G I)$, a circadian regulated gene whose protein product

99 has not only been shown to regulate photoperiodic flowering and various developmental

100 processes but has also been implicated in mediating cold stress and salinity stress responses

101 (Cao, Ye \& Jiang, 2005; Penfield S, Hall A. 2009; Park, Kim \& Yun, 2013; Li et al., 2017), were

102 used to verify the selected RGs.

103 MATERIALS AND METHODS

104 Plant Materials and Stress Treatments

105 S. chamaejasme seeds were collected from Qilian, Qinghai province. After peeling, the seeds

106 were treated with $98 \% \mathrm{H}_{2} \mathrm{SO}_{4}$ for $9-11 \mathrm{~min}$ and were then rinsed for $30 \mathrm{~min}$ with running water

107 and planted in individual pots $(14.5 \times 14.5 \times 6.5 \mathrm{~cm})$ filled with nutrition soil, vermiculite and

108 perlite $(6: 1: 1)$. Germinated seeds were grown 7 weeks and were then transferred to nurseries

109 potted with double-layered filter paper for 3 days of adaptation cultivation. All of the nursery

110 pots were placed in an artificial climate chamber at a temperature of $25 \pm 2{ }^{\circ} \mathrm{C}$ during the day

111 and $15 \pm 2{ }^{\circ} \mathrm{C}$ at night, with a relative humidity of $50-55 \%$ and illumination intensity of 300

$112 \mu \mathrm{mol} \mathrm{m}{ }^{-2} \mathrm{~s}^{-1}$ (14/ $10 \mathrm{~h}$, day/ night). Three pots of 7-week-old seedlings (three biological

113 replicates) with a consistent growth status for each group were chosen and treated with abiotic

114 stresses and hormone treatments.

115 For drought and salt treatments, 20\% PEG-6000 (w/v, Sangon, China) (Zhuang et al., 2015)

116 and $300 \mathrm{mM} \mathrm{NaCl}$ (Sangon, China) (Wang et al., 2015) were applied to irrigate the seedlings,

117 respectively. For cold stress, the seedlings in the nursery pots were shifted to another artificial

118 climate chamber at $4^{\circ} \mathrm{C}$. For hormone treatments, the leaves were sprayed with $0.1 \mathrm{mM}$ ABA

119 (Reddy et al., 2016; Wan et al., 2017), 0.1 mM GA (Li et al., 2016b), or 1.5 mM ETH (Wu et al.,

120 2016). Seedlings were irrigated or sprayed every 12 hours during the course of the experiment.

121 Complete seedlings were carefully collected at $0 \mathrm{~h}, 3 \mathrm{~h}, 12 \mathrm{~h}, 24 \mathrm{~h}$, and $48 \mathrm{~h}$ after treatments;

122 immediately frozen in liquid nitrogen; and stored at $-80^{\circ} \mathrm{C}$ refrigerator until total RNA isolation.

\section{Total RNA Isolation and First Strand cDNA Synthesis}

124 Five random individual plants, approximately $100 \mathrm{mg}$ of seedlings in each sample, were used for

125 total RNA isolation with a TRNzol reagent kit (TIANGEN, China). The concentration and

$126260 / 280$ and 260/230 ratios of the RNA samples were detected with a Nano Drop ND-1000

127 Spectrophotometer (Nano Drop Technologies, USA), and the integrity of all of the RNA samples

128 was verified by $1.0 \%(\mathrm{w} / \mathrm{v})$ agarose gel electrophoresis (AGE). Subsequently, for reverse

129 transcription PCR (RT-PCR) and qRT-PCR, a total of $3.0 \mu \mathrm{g}$ of RNA was DNase I (Ambion,

130 USA) treated and purified and then used to synthesize first strand cDNA by reverse transcription

131 (Roche, USA) in a $20 \mu \mathrm{l}$ reaction system. Finally, cDNA diluted 50-fold with $\mathrm{ddH}_{2} \mathrm{O}$, was used

132 as the template for PCR amplification.

\section{Candidate RG Selection and Primer Design}

134 Ten candidate RGs from the local S. chamaejasme transcriptome database were selected by using 135 local NCBI-blast (version 2.4.0+). The sequences of these genes were used to design the qRT-

136 PCR primers using Primer 5.0, Oligo 7.60 and Beacon Designer 8.20 software with the following 
137 criteria: melting temperature ${ }^{\mathrm{TM}}$ of $50-65^{\circ} \mathrm{C}$, primer lengths of $17-25 \mathrm{bp}$, GC contents of $45-$

$13855 \%$ and product lengths of $90-300 \mathrm{bp}$. The specificity of all of the selected primer pairs was

139 observed via RT-PCR using the cDNA of control groups at $0 \mathrm{~h}$ as the template, and each gene

140 fragmentation was underpinned by $2.0 \%(\mathrm{w} / \mathrm{v})$ AGE and sequenced to ensure its reliability.

\section{RT-PCR and qRT-PCR Analysis}

142 To confirm the specificity of each primer that we designed, we performed RT-PCR in a $25 \mu 1$

143 system using the Bio-Rad C1000 PCR system (Bio-Rad, USA). The reaction system was as

144 follows: $2.5 \mu \mathrm{l}$ of Ex Taq buffer, $2 \mu 1$ of dNTPs, $0.125 \mu 1$ of TaKaRa Ex Taq (TaKaRa, China),

$14560 \mathrm{ng}$ of cDNA template, $0.2 \mu \mathrm{M}$ reverse primer, $0.2 \mu \mathrm{M}$ forward primer, and $\mathrm{ddH}_{2} \mathrm{O}$ to $25 \mu \mathrm{L}$.

146 The RT-PCR reaction parameters were: $95^{\circ} \mathrm{C}$ for $3 \mathrm{~min}, 40$ cycles at $95^{\circ} \mathrm{C}$ for $30 \mathrm{~s}, 58^{\circ} \mathrm{C}$ for $30 \mathrm{~s}$,

$14772^{\circ} \mathrm{C}$ for $20 \mathrm{~s}$, and $72^{\circ} \mathrm{C}$ for $5 \mathrm{~min}$. The amplification products were evaluated by $2.0 \%(\mathrm{w} / \mathrm{v})$

148 AGE. To further confirm that the amplicon corresponded to the target sequence, PCR products

149 contained in the agarose gel were extracted using a TIANgel Midi Purification Kit (TIANGEN,

150 China) and then sequenced using the dideoxy chain-termination method by Sangon Biotech

151 (Shanghai) Co., Ltd.

152 qRT-PCR reactions were carried out with the Fast Start Universal SYBR GreenMaster

153 (Roche, Germany) on a Bio-Rad CFX96 Real-Time PCR system (Bio-Rad, USA) in accordance

154 with the manufacturer's instructions. Reactions were conducted at $95^{\circ} \mathrm{C}$ for 3 min as an initial

155 denaturation, followed by 40 cycles at $95^{\circ} \mathrm{C}$ for $10 \mathrm{~s}, 58^{\circ} \mathrm{C}$ for $10 \mathrm{~s}$, and $72^{\circ} \mathrm{C}$ for $20 \mathrm{~s}$. The

156 melting curves, ranging from $58^{\circ} \mathrm{C}$ to $95^{\circ} \mathrm{C}$, were determined to check the specificity of the

157 amplicons. In the negative control group, qRT-PCR was performed using water instead of cDNA

158 as the template. Three technical replicates were analyzed for each biological sample, and the

159 final $\mathrm{Ct}$ values for each set of samples were the average of three biological replicates. A total of

16045 cDNA samples from five time points in the control groups were used to determine the mean

161 amplification e $\square$ ciency (E) of each primer pair with the LinRegPCR program (Ruijter et al.,

162 2009; Zhuang et al., 2015; Vavrinova, Behuliak \& Zicha, 2016; Wu et al., 2016).

\section{Data Analysis of Gene Expression Stability}

164 Three different types of statistical tools: geNorm (version 3.5), NormFinder (version 0.953) and

165 BestKeeper (version 1.0), were applied to rank the expression stability of the RGs across all of

166 the experimental sets. For geNorm and NormFinder, the raw $\mathrm{Ct}$ values calculated by the CFX

167 equipment ${ }^{\mathrm{TM}}$ software were converted into the relative quantities using the formula $2^{-\Delta \mathrm{Ct}}(\Delta \mathrm{Ct}$

168 = each corresponding $\mathrm{Ct}$ value - lowest $\mathrm{Ct}$ value) for gene expression profiling. For BestKeeper,

169 the raw $\mathrm{Ct}$ values and amplification efficiencies estimated by the LinRegPCR program were used

170 to calculate the coefficient of variation (CV) and standard deviation (SD). The RG with the

171 lowest $\mathrm{CV} \pm \mathrm{SD}$ value was identified as the most stable gene, and the RG with SD value greater

172 than 1.0 was judged to be unstable and should be avoided for gene expression normalization

173 (Guenin et al., 2009). geNorm software was also used to determine the proper RG numbers with

174 pair wise variation $(\mathrm{Vn} / \mathrm{Vn}+1, \mathrm{n}$ refers to the $\mathrm{RGs}$ number) between two sequential normalization

175 factors.

\section{Validation of Reference Genes}


177 To test the accuracy of the results, the geometric mean from the sort results of geNorm,

178 NormFinder, and BestKeeper in each subset were used to calculate the comprehensive ranking of

179 the candidate genes. The smaller the comprehensive ranking results, the better the gene

180 expression stability. Then, the combination of the top two best RGs, best ranked RG and worst

181 ranked RG were used to standardize the expression of two target genes, i.e., P5CS2 and GI,

182 under different experimental conditions. Furthermore, the expression levels of P5CS2 and GI

183 under salt stress calculated by the combination of the top two best RGs were also compared with

184 the FPKM values in the $S$. chamaejasme transcriptome database.

185 RESULTS

\section{Selection of Candidate RGs and Target Genes}

187 After comparing the reported RGs in other species with the local transcriptome database of $S$.

188 chamaejasme using the local Blast program, ten RGs and two target genes were chosen to

189 perform the gene normalization studies. The results showed that the $\mathrm{E}$ value of each blast gene

190 indicated high homology. The untranslated region (UTR) of these full-length unigene sequences

191 were used to design the specific primers for RT-PCR and qRT-PCR. The unigene ID, NCBI

192 accession number, gene symbol, gene name, homolog locus of 10 candidate RGs and two target

193 genes, and E value compared with those of the homologous genes are listed in Table 1.

\section{Verification of the Primer Specificity and qRT-PCR Amplification Efficiency}

195 The specificity of each primer was tested by $2.0 \%$ AGE, sequencing and melting curves analysis, 196 which provided the expected amplicon length (Supplemental figure 1) and single peak melting

197 curves (Supplemental figure 2). The primer sequences, amplicon size, product Tm,

198 amplification e $\square$ ciencies, and other relevant information are given in Table 2. The amplification

199 product length of PCR varied from $94 \mathrm{bp}$ to $267 \mathrm{bp}$. The Tm for all PCR products spanned from

200

201

202

203

204

205

206

207

208

209

210

211

212 $76.0^{\circ} \mathrm{C}$ for $M D H$ to $83.5^{\circ} \mathrm{C}$ for $G A P C P 1$. The E-values of these genes were between 1.824 $(M D H)$ and $1.930(G A P D H 2)$, and the linear correlation coe $\square$ cients $\left(\mathrm{R}^{2}\right)$ varied from 0.994 (SAND) to 0.998 (CYP). In conclusion, we had every reason to believe that all of these specificity and efficiency estimates of the amplification were reliable for further analysis.

\section{Expression Profiles of Candidate RGs}

Boxplot analysis of the $\mathrm{Ct}$ values of different reference genes in all of the experimental samples was performed using origin 2017 software (Fig. 1). The results demonstrated that the mean $\mathrm{Ct}$ values of the ten candidate RGs presented a relatively wide field, from 19.26 to 30.76 . $60 \mathrm{~S}$ showed the least expression variation, while $18 S$ exhibited the highest variation, with the $\mathrm{Ct}$ values ranging from 15.58 to 22.59 . Since the $\mathrm{Ct}$ values are negatively related to the gene expression levels, the smaller the $\mathrm{Ct}$ value, the higher the gene expression level. As Fig. 1 shows, $18 S$ was the highest-expressed RG for its lowest mean Ct value (15.58), and GAPCPl had the lowest expression level on account of its maximum mean Ct value (32.58).

\section{Analysis of Gene Expression Stability}

214 geNorm analysis. geNorm calculates the gene expression stability measure $\mathrm{M}$ value as the

215 average pairwise variation V for the RG and other tested RGs (Vandesompele et al., 2002). The 
216 smaller the $M$ value, the more stable the gene, and vice versa. In our study, the $M$ values of the

21710 candidate RGs of $S$. chamaejasme calculated by geNorm software were below 1.5 in all of the

218 experimental settings (Fig. 2), suggesting that these genes should be considered relatively stable.

219 As described in Fig. 2A, Fig. 2B and Fig. 2C, GAPCPI and EF1B under drought stress,

$220 G A P C P 1$ and $60 S$ under cold stress, and $E F 1 B$ and $60 S$ under salt stress were the most stable RGs

221

222

223

224

225

226

227

228

229

230

231

232

233

234

235

236

237

238

239

240

241

242

243

244

245

246

247

248

249

250

251 with the lowest $\mathrm{M}$ values of $0.07,0.05$ and 0.19 , respectively. At the same time, in the ABA (Fig. 2D), GA (Fig. 2E), and ETH (Fig. 2F) treatment groups, SAND and TUA6, TUA1 and CYP, $G A P D H 2$ and $60 S$ were considered to be the most stable genes with the lowest $\mathrm{M}$ values of 0.21 , 0.22 and 0.19 , respectively. In addition, for all of the sample sets (Fig. 2G), GAPCP1 and CYP were suggested to be two most stable RGs. On the contrary, $18 S$ was the least stable gene in all of the sets except for ETH treatment, in which TUA6 was the least stable gene.

NormFinder analysis. NormFinder provides a stability value for each gene by analyzing expression data obtained through qRT-PCR, which is a direct measurement for estimating expression variation when the gene is used for normalization (Dheda et al., 2005). The orders based on the stability values calculated by NormFinder (Table 3) were similar to those determined by geNorm. The stability ranking results under cold stress and in the GA treatment subsets were completely consistent with the results determined through geNorm; meanwhile, TUA6 and $18 S$ were the two least stable genes for ETH treatment and the rest of the treatments. For the cold stress group, GAPCPI and $E F 1 B$ were the two most stable RGs (also ranked first by geNorm). For the salt stress group, GAPCP1 and TUA1 were the two most stable RGs, which was different from the geNorm results. For all samples, ABA-treated and ETH-treated subsets, NormFinder suggested that GAPCP1 and $60 S, T U A 1$ and $S A N D, G A P D H 2$ and $60 S$ were the most stable RGs, respectively, which were not exactly the same as the geNorm analysis results.

BestKeeper analysis. BestKeeper evaluates the RG expression stability by calculating the $\mathrm{CV}$ and $\mathrm{SD}$ of the average $\mathrm{Ct}$ values. A lower $\mathrm{CV}$ value indicates more stable $\mathrm{RG}$ expression (Guenin et al., 2009). As shown in Table 4, under drought stress and for all of the sample subsets, TUA1 had the lowest $\mathrm{CV} \pm \mathrm{SD}$ values of $0.52 \pm 0.16$ and $0.53 \pm 0.16$ and was considered to be the most stable RG. Under the cold stress condition and salt stress and ABA treatment subsets, $E F 1 B$, which had the lowest $\mathrm{CV} \pm \mathrm{SD}$ values of $1.16 \pm 0.31,1.35 \pm 0.36$ and $1.04 \pm 0.27$, respectively, was identified as the best RG. In the GA treatment subset, TUA6 had the lowest $\mathrm{CV} \pm \mathrm{SD}$ value of $0.82 \pm 0.22$ and was the most stable. In the ETH treatment subset, BestKeeper suggested that $G A P D H 2$ was the most stable $\mathrm{RG}$ with the lowest $\mathrm{CV} \pm \mathrm{SD}$ value of $0.68 \pm 0.18$. Additionally, only a few genes had a SD value greater than 1.0 , indicating that most of the candidate RGs were relatively stable. Except for the ETH treatment subset, the most unstable RG among all of the experimental settings was $18 S$, which was the same as the results of geNorm and NormFinder.

\section{Determination of the Optimal Number of RGs}

253 At the suggestion of the geNorm Service tool, the critical value $\mathrm{Vn} / \mathrm{Vn}+1$ to determine the 254

255

256

257 optimal RG number for qRT-PCR normalization is 0.15 , below which the inclusion of an additional RG is not required (Vandesompele et al., 2002). As Fig. 3 shows, the V2/3 values of all of the experimental groups were less than 0.15 , which indicated that a two RG combination would be sufficient to use for normalization. 


\section{Comprehensive Stability Analysis of RGs}

259 Table 5 and Fig. 4 summarize and rank the determination results obtained from the geNorm,

260 NormFinder and Bestkeeper programs. Based on the analysis, GAPCP1 and EF $1 B$ were the most 261 stable RGs under three abiotic stresses; thus, TUA6 and SAND, TUA1 and CYP, GAPDH2 and

$26260 S$ were the best RG combinations under the ABA, GA and ETH treatments, respectively. Still,

$26318 S$ was the most unstable RG under all of the experimental conditions.

\section{Reference Gene Validation}

265

266

267

268

269

270

271

272

273

274

275

276

277

278

279

280

281

282

283

284

285

286

287

288

289

290

291

292

293

294

295

296

297

298

As shown in Fig. 5 and Fig. 6, when the best RG combinations were used for performing normalization, the expression levels of P5CS2 and GI were affected by different treatments. A sustained increase in expression level of P5CS2 was observed after drought stress, and a peak point was observed at $48 \mathrm{~h}$ (Fig. 5A). A tendency of first increase, after downward, and then upward in the transcript level of P5CS2 appeared after cold and GA treatments (Fig. 5B and 5E). Additionally, upregulated expression of P5CS2 was observed after salt and ABA treatments, and reached the maximum value at $12 \mathrm{~h}$ and $24 \mathrm{~h}$ following a decrease (Fig. 5C and 5D). Whereas, P5CS2 expression was first downregulated at $3 \mathrm{~h}$ after ETH treatment and then began to continuous increase, reaching the maximum at $48 \mathrm{~h}(\mathbf{F i g}$. 5F). The maximal expression levels of GI under drought (Fig. 6A), cold (Fig. 6B), salt (Fig. 6C), ABA (Fig. 6D) and ETH (Fig. 6F) treatments also appeared prominent changes, which were 4.66-fold, 29.22-fold, 2.10-fold, 6.45fold and 2.45-fold higher than those of the control group, while there was no significant difference under GA treatment (Fig. 6E).

Compared with the best RG combinations for normalization of P5CS and G1, similar expression patterns were obtained when the most stable single genes, GAPCP1 (drought and cold), EF1B (salt), TUA6 (ABA), TUA1 (GA) and GAPDH2 (ETH), were used for normalization under the above treatments. However, different expression patterns were generated and the expression levels of P5CS2 and GI were overestimated when the least stable gene, $18 S$, was selected as the RG for normalization.

In particular, as shown in Fig. 5C, under salt treatment, when the RG combination (GAPCPI and $E F 1 B$ ) was selected for normalization, gene expression of $P 5 C S 2$ gradually increased from 0 $\mathrm{h}$, reached the maximum at $24 \mathrm{~h}$, and then began to slightly decline at $48 \mathrm{~h}$. In the same way, the expression levels of $G I$ increased at first, then decreased and maintained a lower level until $48 \mathrm{~h}$ (Fig. 6C). The expression trends of P5CS2 and GI over the first 24 hours were generally consistent with those of RNA-seq (Supplemental figure 3), which further validated the accuracy and reliability of our experimental results.

\section{DISCUSSION}

qRT-PCR is currently viewed as a powerful technique that can be used to quantify target gene expression. The accuracy of qRT-PCR directly depends on the stability of the internal genes used. The use of inappropriate RGs for normalizing qRT-PCR data will lead to deviations in the results (Shivhare \& Lata, 2016). In this study, three programs, geNorm, NormFinder and Bestkeeper, were used to select optimum RGs for six different experimental conditions. The ten potential RGs exhibited differential stability in response to different stresses. Taking ABA treatment as an example, in the experimental subset, geNorm software ranked $S A N D$ as the best 
299 RG, and NormFinder regarded TUA1 as the most stable RG. However, Bestkeeper identified

$300 E F 1 B$ as the best RG according to its lowest $\mathrm{CV}$ value. This means that the three types of

301 software generated different results, and a solution was not found. Our study carried out a

302 comprehensive analysis and provided ultimate stability ordering results by ranking the geometric

303 means of the three software analysis results, which is a common strategy for evaluating the

304 expression stability of RGs reported in previous scientific papers.

$305 E F 1 B$ catalyzes the exchange of guanosine diphosphate (GDP) bound to the G-protein, 306 elongation factor 1-alpha (EF1A), for guanosine triphosphate (GTP), an important step in the

307 elongation cycle of protein biosynthesis. It has been considered to be one of the most stable

308 reference genes during drought and salt stresses (Wan et al. 2017) and other stress conditions

309 (Ma et al., 2013). In our study, EF1B was ranked as one of the two best RGs under drought and

310 salt stresses according to the comprehensive ranking results, which was the same as in Stipa

311 grandis (Wan et al. 2017). In addition, EFIB performed a better expression stability under three

312 abiotic stresses than those in the three hormone treatments. The results showed that there are no

313 universal RGs that are stably expressed in all biological materials and/or under all trial

314 conditions.

315 The expression stability of two homologous RGs, TUA1 and TUA6, were estimated in our study.

316 According to the results, the stability ranking of TUAl was always better than that of TUA6

317 under all conditions except the ABA treatment, under which TUA6 exhibited better expression

318 stability. Nevertheless, it is notable that the homologous RGs showed different rank orders in

319 each subset, and in most cases, TUA1 showed better expression stability than TUA6. Cordoba et

320 al. (2011) found that TUAl was one of the most suitable reference genes under $\mathrm{NaCl}$ stress and

321 2,4-dichlorophenoxyacetic acid treatment in Hedysarum coronarium. However, Gimeno et al.

322 (2014) suggested that TUA6 should be discard for normalization under drought stress, salt stress,

323 cold and heat shock treatment, and flooding treatment in switchgrass. Although these reports

324 indicated the expression stability of TUAI and TUA6 in different species, respectively, but at

325 present we have not found any reports of the simultaneous use of TUA1 and TUA6 in stability

326 analysis in other species. Therefore, this does not mean that the expression stability of TUA1 in

327 other species must be better than that of TUA6.

$18 S$ is a frequently used HKG and is widely used for normalization in qRT-PCR analysis. Wang et al. (2017) reported that $18 S r R N A$ was one of the most stably expressed gene under diverse heavy metals stresses in tea plants; Huang et al.(2017) also found that $18 S$ rRNA was the

331

332

333

334

335

336

337 most stable gene under UV irradiation and hormonal stimuli in Baphicacanthus cusia. However, our analysis results suggested that $18 S$ was the most unstable RG in all of the experiment groups because of its excessively high expression level. In comparison with the best RG combination and the most stable $\mathrm{RG}$, when $18 S$ was selected as a RG to validate the expression of the two target genes P5CS2 and GI, their expression patterns were significantly overestimated, which was consistent with the findings in Oxytropis ochrocephala (Zhuang et al., 2015) and rice (Bevitori et al., 2014).

Two target genes, P5CS2 and GI, were used to verify the stability of the selected RGs for gene expression normalization. Strizhov et al. (1997) stated that expression of Arabidopsis thaliana

340 P5CS (AtP5CS) is root and leaf specific and can be regulated by salinity, drought and ABA. The

341 same experimental results were reproduced in our experiments. We also found that P5CS could 
342 be efficiently expressed during the later period of cold stress, which may be a supplement to 343 previous findings. The induction mechanism remains to be further studied. Cao, Ye and Jiang 344 (2005) reported that GI is induced by cold stress, but not by salt, mannitol, and ABA. By 345 contrast, Park, Kim and Yun (2013) and Kim et al. (2013) claimed that GI, as a negative 346 regulator, participated in the regulation of salt stress in Arabidopsis by interacting with salt overly sensitive 2 (SOS2). Moreover, Riboni et al. (2016) revealed that ABA affects flowering through two independent regulatory mechanisms: activation of $G I$ and constant $(C O)$ functions upstream of the florigen genes and down-regulation of the suppressor of overexpression of $\mathrm{CO} 1$ ( $S O C 1$ ) signaling. Our findings indicated that the gene expression of $G I$ not only changed under salt stress and cold stress but also underwent a significant change under drought, ABA and ETH treatments. We have reason to believe that these mechanisms will be revealed with future indepth experiments.

There is no doubt that it is necessary to select suitable RGs and/or RG combinations for gene normalization studies to obtain more accurate and reliable results. Combined with all of the validation results above, we observed that, in most cases, P5CS2 and GI showed similar response patterns when normalized by the most stable RGs combinations, but some differences still emerged. Unfortunately, we could not tell which choice was better for normalization. However, to eliminate the small variations caused by technical protocols in qRT-PCR, two or more RGs are often required to correct for non-specific experimental variation (Thellin et al., 1999; Bustin et al., 2009). In this study, two RG combinations, whose V2/3 values were less than 0.15 across all of the experimental subsets and thus GAPCPI and $E F 1 B$ for drought stress, cold stress and salt stress, TUA6 and SAND for ABA treatment, TUAI and CYP for GA treatment, and GAPDH2 and $60 S$ for ETH treatment, were suggested for the accurate normalization of target gene expression.

\section{CONCLUSIONS}

This study represents the first attempt to comprehensively analyze the stability of RGs for use as internal controls in qRT-PCR analysis of target gene expression in $S$. chamaejasme under three abiotic stresses and three hormone treatments by combining results from three different methods. The results indicated that the stability of an identical gene was not exactly the same under different treatments, and the stability ranking of the RGs calculated by three parameters was not identical under the same treatment. As a result, it makes sense to carry out a comprehensive analysis of the results of the three procedures. Moreover, it may be a better choice to select a combination of two or more RGs as an effective internal control to further improve the accuracy and reliability of gene expression normalization under different stresses. In conclusion, this study provides a guideline to select a valid RG combination that can ensure more accurate qRT-PCRbased gene expression quantification and basic data to facilitate future molecular studies on gene expression in S. chamaejasme and other Thymelaeaceae species (Che et al., 2016).

\section{ACKNOWLEDGEMENTS}

The authors are particularly grateful to Jiakun Dai, Na Fan, Shilan Feng, and other members of our research group for their helpful comments/suggestions to improve the experimental design.

\section{REFERENCES}


383

384

385

386

387

388

389

390

391

392

393

394

395

396

397

398

399

400

401

402

403

404

405

406

407

408

409

410

411

412

413

414

415

416

417

418

419

420

421

422

Andersen CL, Jensen JL, and Orntoft TF. 2004. Normalization of real-time quantitative reverse transcription-PCR data: a model-based variance estimation approach to identify genes suited for normalization, applied to bladder and colon cancer data sets. Cancer Research 64:5245-5250. DOI: 10.1158/0008-5472.CAN-04-0496

Bevitori R, Oliveira MB, Grossi-de-Sa MF, Lanna AC, da Silveira RD, and Petrofeza S. 2014. Selection of optimized candidate reference genes for qRT-PCR normalization in rice (Oryza sativa L.) during Magnaporthe oryzae infection and drought. Genetics and Molecular Research 13:9795-9805. DOI: 10.4238/2014.November.27.7

Bustin SA, Benes V, Garson JA, Hellemans J, Huggett J, Kubista M, Mueller R, Nolan T, Pfaffl MW, Shipley GL, Vandesompele J, and Wittwer CT. 2009. The MIQE guidelines: minimum information for publication of quantitative real-time PCR experiments. Clinical Chemistry 55:611-622. DOI: 10.1373/clinchem.2008.112797

Cao J, Wang L, and Lan H. 2016. Validation of reference genes for quantitative RT-PCR normalization in Suaeda aralocaspica, an annual halophyte with heteromorphism and C4 pathway without Kranz anatomy. PeerJ 4:e1697. DOI: 10.7717/peerj.1697

Cao S, Ye M, and Jiang S. 2005. Involvement of GIGANTEA gene in the regulation of the cold stress response in Arabidopsis. Plant Cell Reports 24:683-690. DOI: 10.1007/s00299005-0061-x

Che JX, Shi JL, Lu Y, and Liu YL. 2016. Validation of reference genes for normalization of gene expression by qRT-PCR in a resveratrol-producing entophytic fungus (Alternaria sp. MG1). AMB Express 6:106. DOI: 10.1186/s13568-016-0283-Z

Chen Y, Hu B, Tan Z, Liu J, Yang Z, Li Z, and Huang B. 2015. Selection of reference genes for quantitative real-time PCR normalization in creeping bentgrass involved in four abiotic stresses. Plant Cell Rep 34:1825-1834. DOI: 10.1007/s00299-015-1830-9

Cordoba EM, Die JV, Gonzalez-Verdejo CI, Nadal S, and Roman B. 2011. Selection of reference genes in Hedysarum coronarium under various stresses and stages of development. Anal Biochem 409:236-243. DOI: 10.1016/j.ab.2010.10.031

Demidenko NV, Logacheva MD, and Penin AA. 2011. Selection and validation of reference genes for quantitative real-time PCR in buckwheat (Fagopyrum esculentum) based on transcriptome sequence data. PLoS One 6:e19434. DOI: 10.1371/journal.pone.0019434

Derveaux S, Vandesompele J, and Hellemans J. 2010. How to do successful gene expression analysis using real-time PCR. Methods 50:227-230. DOI: 10.1016/j.ymeth.2009.11.001

Dheda K, Huggett JF, Chang JS, Kim LU, Bustin SA, Johnson MA, Rook GAW, and Zumla A. 2005. The implications of using an inappropriate reference gene for real-time reverse transcription PCR data normalization. Analytical Biochemistry 344:141-143. DOI: 10.1016/j.ab.2005.05.022

Ferraz Dos Santos L, Santana Silva RJ, Oliveira Jordao do Amaral D, Barbosa de Paula MF, Ludke Falcao L, Legavre T, Alves RM, Marcellino LH, and Micheli F. 2016. Selection of reference genes for expression study in pulp and seeds of Theobroma grandiflorum (Willd. ex Spreng.) Schum. PLoS One 11:e0160646. DOI: 10.1371/journal.pone.0160646 
423

424

425

426

427

428

429

430

431

432

433

434

435

436

437

438

439

440

441

442

443

444

445

446

447

448

449

450

451

452

453

454

455

456

457

458

459

460

461

462

Fiume E, and Fletcher JC. 2012. Regulation of Arabidopsis embryo and endosperm development by the polypeptide signaling molecule CLE8. Plant Cell 24:1000-1012. DOI: $10.1105 /$ tpc. 111.094839

Gimeno J, Eattock N, Van Deynze A, and Blumwald E. 2014. Selection and validation of reference genes for gene expression analysis in switchgrass (Panicum virgatum) using quantitative real-time RT-PCR. PLoS One 9:e91474. DOI: 10.1371/journal.pone.0091474

Gong L, Yang Y, Chen Y, Shi J, Song Y, and Zhang H. 2016. LbCML38 and LbRH52, two reference genes derived from RNA-Seq data suitable for assessing gene expression in Lycium barbarum L. Scientific Reports 6:37031. DOI: 10.1038/srep37031

Guenin S, Mauriat M, Pelloux J, Van Wuytswinkel O, Bellini C, and Gutierrez L. 2009. Normalization of qRT-PCR data: the necessity of adopting a systematic, experimental conditions-specific, validation of references. Journal of Experimental Botany 60:487493. DOI: $10.1093 / \mathrm{jxb} / \mathrm{ern} 305$

Huang Y, Tan H, Yu J, Chen Y, Guo Z, Wang G, Zhang Q, Chen J, Zhang L, and Diao Y. 2017. Stable internal reference genes for normalizing real-time quantitative PCR in Baphicacanthus cusia under hormonal stimuli and UV irradiation, and in different Plant organs. Front Plant Sci 8:668. DOI: 10.3389/fpls.2017.00668

Huggett J, Dheda K, Bustin S, and Zumla A. 2005. Real-time RT-PCR normalisation; strategies and considerations. Genes and Immunity 6:279-284. DOI: 10.1038/sj.gene.6364190

Kim WY, Ali Z, Park HJ, Park SJ, Cha JY, Perez-Hormaeche J, Quintero FJ, Shin G, Kim MR, Qiang Z, Ning L, Park HC, Lee SY, Bressan RA, Pardo JM, Bohnert HJ, and Yun DJ. 2013. Release of SOS2 kinase from sequestration with GIGANTEA determines salt tolerance in Arabidopsis. Nat Commun 4:1352. DOI: 10.1038/ncomms2357

Li J, Jia H, Han X, Zhang J, Sun P, Lu M, and Hu J. 2016a. Selection of reliable reference genes for gene expression analysis under abiotic stresses in the desert biomass willow, Salix psammophila. Frontiers in Plant Science 7:1505. DOI: 10.3389/fpls.2016.01505

Li MY, Song X, Wang F, and Xiong AS. 2016b. Suitable reference genes for accurate gene expression analysis in parsley (Petroselinum crispum) for abiotic stresses and hormone stimuli. Frontiers in Plant Science 7:1481. DOI: 10.3389/fpls.2016.01481

Li S, Ying Y, Secco D, Wang C, Narsai R, Whelan J, and Shou H. 2017. Molecular interaction between PHO2 and GIGANTEA reveals a new crosstalk between flowering time and phosphate homeostasis in Oryza sativa. Plant, Cell \& Environment 40:1487-1499. DOI: $10.1111 /$ pce. 12945

Ma S, Niu H, Liu C, Zhang J, Hou C, and Wang D. 2013. Expression stabilities of candidate reference genes for RT-qPCR under different stress conditions in soybean. PLoS One 8:e75271. DOI: 10.1371/journal.pone.0075271

Nicot N, Hausman JF, Hoffmann L, and Evers D. 2005. Housekeeping gene selection for realtime RT-PCR normalization in potato during biotic and abiotic stress. Journal of Experimental Botany 56:2907-2914. DOI: 10.1093/jxb/eri285 
463 Paolacci AR, Tanzarella OA, Porceddu E, and Ciaffi M. 2009. Identification and validation of

464

465

466

467

468

469

470

471

472

473

474

475

476

477

478

479

480

481

482

483

484

485

486

487

488

489

490

491

492

493

494

495

496

497

498

499

500

501

502 reference genes for quantitative RT-PCR normalization in wheat. Bmc Molecular Biology 10:11. DOI: 10.1186/1471-2199-10-11

Park HJ, Kim WY, and Yun DJ. 2013. A role for GIGANTEA: keeping the balance between flowering and salinity stress tolerance. Plant Signaling and Behavior 8:e24820. DOI: $10.4161 / \mathrm{psb} .24820$

Penfield S, Hall A. 2009. A role for multiple circadian clock genes in the response to signals that break seed dormancy in Arabidopsis. Plant Cell 21:1722-32. DOI: 10.1105/tpc.108.064022.

Pfaffl MW, Tichopad A, Prgomet C, and Neuvians TP. 2004. Determination of stable housekeeping genes, differentially regulated target genes and sample integrity: BestKeeper--Excel-based tool using pair-wise correlations. Biotechnology Letters 26:509-515.

Qi S, Yang L, Wen X, Hong Y, Song X, Zhang M, and Dai S. 2016. Reference gene selection for RT-qPCR analysis of flower development in Chrysanthemum morifolium and Chrysanthemum lavandulifolium. Frontiers in Plant Science 7:287. DOI: 10.3389/fpls.2016.00287

Reddy DS, Bhatnagar-Mathur P, Reddy PS, Sri Cindhuri K, Sivaji Ganesh A, and Sharma KK. 2016. Identification and validation of reference genes and their impact on normalized gene expression studies across cultivated and wild Cicer species. PLoS One 11:e0148451. DOI: 10.1371/journal.pone.0148451

Riboni M, Robustelli Test A, Galbiati M, Tonelli C, and Conti L. 2016. ABA-dependent control of GIGANTEA signalling enables drought escape via up-regulation of FLOWERING LOCUS T in Arabidopsis thaliana. Journal of Experimental Botany 67:6309-6322. DOI: $10.1093 / \mathrm{jxb} / \mathrm{erw} 384$

Ruijter JM, Ramakers C, Hoogaars WM, Karlen Y, Bakker O, van den Hoff MJ, and Moorman AF. 2009. Amplification efficiency: linking baseline and bias in the analysis of quantitative PCR data. Nucleic Acids Research 37:e45. DOI: 10.1093/nar/gkp045

Shi Z, and Wei Y. 2016. Important poisonous plants of china grassland. Beijing: China Agriculture Press.

Shivhare R, and Lata C. 2016. Selection of suitable reference genes for assessing gene expression in pearl millet under different abiotic stresses and their combinations. Scientific Reports 6:23036. DOI: 10.1038/srep23036

Strizhov N, Abraham E, Okresz L, Blickling S, Zilberstein A, Schell J, Koncz C, and Szabados L. 1997. Differential expression of two P5CS genes controlling proline accumulation during salt-stress requires ABA and is regulated by ABA1, ABI1 and AXR2 in Arabidopsis. The Plant Journal 12:557-569.

Taylor CM, Jost R, Erskine W, and Nelson MN. 2016. Identifying stable reference genes for qRT-PCR normalisation in gene expression studies of narrow-leafed lupin (Lupinus angustifolius L.). PLoS One 11:e0148300. DOI: 10.1371/journal.pone.0148300 
503 Thellin O, Zorzi W, Lakaye B, De Borman B, Coumans B, Hennen G, Grisar T, Igout A, and

504

505

506

507

508

509

510

511

512

513

514

515

516

517

518

519

520

521

522

523

524

525

526

527

528

529

530

531

532

533

534

535

536

537

538

539

540
Heinen E. 1999. Housekeeping genes as internal standards: use and limits. Journal of Experimental Botany 75:291-295.

Tseng YC. 1999. Flora Reipublicae Popularis Sinicae. Beijing: Science Press. p 397.

Vandesompele J, De Preter K, Pattyn F, Poppe B, Van Roy N, De Paepe A, and Speleman F. 2002. Accurate normalization of real-time quantitative RT-PCR data by geometric averaging of multiple internal control genes. Genome Biology 3:RESEARCH0034.

Vavrinova A, Behuliak M, and Zicha J. 2016. The importance of the selection of appropriate reference genes for gene expression profiling in adrenal medulla or sympathetic ganglia of spontaneously hypertensive rat. Physiological Research 65:401-411.

Wan D, Wan Y, Yang Q, Zou B, Ren W, Ding Y, Wang Z, Wang R, Wang K, and Hou X. 2017. Selection of reference genes for qRT-PCR analysis of gene expression in Stipa grandis during environmental stresses. PLoS One 12:e0169465. DOI: 10.1371/journal.pone.0169465

Wang ML, Li QH, Xin HH, Chen X, Zhu XJ, and Li XH. 2017. Reliable reference genes for normalization of gene expression data in tea plants (Camellia sinensis) exposed to metal stresses. PLoS One 12:e0175863. DOI: 10.1371/journal.pone.0175863

Wang X, He J, Wang W, Ren M, Gao S, Zhao G, Wang J, and Yang Q. 2016a. Validation of internal reference genes for relative quantitation studies of gene expression in human laryngeal cancer. PeerJ 4:e2763. DOI: 10.7717/peerj.2763

Wang X, Ma X, Huang L, and Zhang X. 2015. Identification of the valid reference genes for quantitative RT-PCR in annual ryegrass (Lolium multiflorum) under salt stress. Molecules 20:4833-4847. DOI: 10.3390/molecules20034833

Wang Y, Chen Y, Ding L, Zhang J, Wei J, and Wang H. 2016b. Validation of reference genes for gene expression by quantitative real-time RT-PCR in stem segments spanning primary to secondary growth in Populus tomentosa. PLoS One 11:e0157370. DOI: 10.1371/journal.pone. 0157370

Warrington JA, Nair A, Mahadevappa M, and Tsyganskaya M. 2000. Comparison of human adult and fetal expression and identification of 535 housekeeping/maintenance genes. Physiological Genomics 2:143-147.

Wu J, Zhang H, Liu L, Li W, Wei Y, and Shi S. 2016. Validation of reference genes for RTqPCR studies of gene expression in preharvest and postharvest Longan fruits under different experimental conditions. Frontier in Plant Science 7:780. DOI: 10.3389/fpls.2016.00780

Zhuang H, Fu Y, He W, Wang L, and Wei Y. 2015. Selection of appropriate reference genes for quantitative real-time PCR in Oxytropis ochrocephala Bunge using transcriptome datasets under abiotic stress treatments. Frontiers in Plant Science 6:475. DOI: 10.3389/fpls.2015.00475 
Table $\mathbf{1}$ (on next page)

Description of candidate reference genes and target genes. 


\begin{tabular}{|c|c|c|c|c|c|}
\hline Unigene Gene ID & $\begin{array}{l}\text { Accession } \\
\text { number }\end{array}$ & $\begin{array}{l}\text { Gene } \\
\text { symbol }\end{array}$ & Gene name & $\begin{array}{l}\text { Homolog } \\
\text { locus }\end{array}$ & E value \\
\hline >c73334.graph_c0 & MG516523 & $18 S$ & $18 \mathrm{~S}$ ribosomal RNA & AH001810 & $1 \mathrm{e}-105$ \\
\hline$>$ >c68075.graph_c0 & MG516524 & $60 S$ & 60S ribosomal RNA & KJ634810 & 0.0 \\
\hline$>c 71629$.graph_c0 & $M G 516525$ & CYP & Cyclophilin & JN032296 & $2 \mathrm{e}-123$ \\
\hline$>c 70757$.graph_c0 & MG516526 & $E F 1 B$ & Elongation factor 1-beta & XM_013599463 & $9 e-138$ \\
\hline$>c 67520$.graph_c0 & MG516527 & GAPCP1 & $\begin{array}{l}\text { Glyceraldehyde-3-phosphate } \\
\text { dehydrogenase of plastid } 1\end{array}$ & NM_106601 & 0.0 \\
\hline$>$ >c74212.graph_c0 & MG516528 & GAPDH2 & $\begin{array}{l}\text { Glyceraledehyde-3-phosphate } \\
\text { dehydrogenase } 2\end{array}$ & KM370884 & 0.0 \\
\hline$>c 70711$.graph_c1 & MG516529 & $M D H$ & Malate dehydrogenase & HQ449567 & 0.0 \\
\hline >c72957.graph_c1 & MG516530 & $S A N D$ & SAND family protein & NM_128399 & 0.0 \\
\hline$>$ c60567.graph_c0 & MG516531 & $T U A 1$ & Alpha-tubulin 1 & AT1G64740 & 0.0 \\
\hline$>$ >c65147.graph_c0 & MG516532 & TUA6 & Alpha-tubulin 6 & AT4G14960 & 0.0 \\
\hline >c57696.graph_c0 & MG516533 & P5CS2 & $\begin{array}{l}\text { Delta 1-pyrroline-5-carboxylate } \\
\text { synthetase } 2\end{array}$ & AT3G55610 & 0.0 \\
\hline$>$ c73625.graph_c0 & MG516534 & GI & GIGANTEA & KR813315 & 0.0 \\
\hline
\end{tabular}

1 
Table 2 (on next page)

Selected candidate RGs and target genes, primers, and amplicon characteristics. 


\begin{tabular}{|c|c|c|c|c|c|}
\hline Name & $\begin{array}{l}\text { Forward primer sequences }\left(5^{\prime}-3^{\prime}\right) \\
\text { Reverse primer sequences }\left(5^{\prime}-3^{\prime}\right)\end{array}$ & $\begin{array}{l}\text { Amplicon } \\
\text { Size (bp) }\end{array}$ & $\begin{array}{l}\text { Product } \\
\operatorname{Tm}^{\mathrm{a}}\left({ }^{\circ} \mathrm{C}\right)\end{array}$ & $\mathbf{E}$ & $\mathbf{R}^{2}$ \\
\hline $18 S$ & $\begin{array}{l}\text { CTATCCAGCGAAACCACAG } \\
\text { CCСACTTATCCTACACCTCTC }\end{array}$ & 122 & $81.5-82.0$ & 1.918 & 0.996 \\
\hline $60 S$ & $\begin{array}{l}\text { TTGTTCGATAGCATCCGTCT } \\
\text { ATAAAAGCAAACAACGGAAGCA }\end{array}$ & 170 & $78.0-78.5$ & 1.836 & 0.997 \\
\hline$C Y P$ & $\begin{array}{l}\text { ACATAGTTTGAGGCAACCTAGCAGT } \\
\text { TACACCTTCGCAGACAGTCGTT }\end{array}$ & 161 & 80.0 & 1.854 & 0.997 \\
\hline$E F 1 B$ & $\begin{array}{l}\text { GCAGTGAACTCTCCCCAG } \\
\text { CCAAACAGGGCATAAAAGAAC }\end{array}$ & 191 & $78.0-79.0$ & 1.842 & 0.998 \\
\hline$G A P C P 1$ & $\begin{array}{l}\text { CCATTAGATCCGTCGCCTGTT } \\
\text { TTGTTGGTGGCACTTCTGTAGC }\end{array}$ & 192 & $83.0-83.5$ & 1.834 & 0.998 \\
\hline GAPDH 2 & $\begin{array}{l}\text { GTGAAACTGGTCTCCTGGTATG } \\
\text { AACCCAGGCAACGCTTATA }\end{array}$ & 115 & 81.0 & 1.930 & 0.998 \\
\hline$M D H$ & $\begin{array}{l}\text { CCGCGACTTTGAATAAGCCCAT } \\
\text { AACTCAAAATCCTCGTCCCCAA }\end{array}$ & 94 & $76.0-76.5$ & 1.824 & 0.997 \\
\hline$S A N D$ & $\begin{array}{l}\text { CCTGCCAAGATACAATCCCA } \\
\text { TTTGTGCTGCCCTAAACGAG }\end{array}$ & 267 & $80.0-80.5$ & 1.872 & 0.997 \\
\hline$T U A 1$ & $\begin{array}{l}\text { GGCACTTTCGAGTTTTCGC } \\
\text { CCAGCTTGTCCGATGTGAA }\end{array}$ & 97 & $79.0-79.5$ & 1.840 & 0.998 \\
\hline TUA6 & $\begin{array}{l}\text { GAAGGAATGGAGGAAGGGGAG } \\
\text { CAAACACAAGAAAGCGACAAATAAG }\end{array}$ & 165 & $81.5-82.5$ & 1.837 & 0.997 \\
\hline P5CS2 & $\begin{array}{l}\text { TGACTTTATACGGTGGACCAA } \\
\text { TCCTCTGTGACAACGCAAT }\end{array}$ & 178 & $82.5-84.5$ & 1.839 & 0.997 \\
\hline$G I$ & $\begin{array}{l}\text { ATGATTACAGAAACGGAATTAACTCA } \\
\text { TAACTCCATGAAGTACCGACAGA }\end{array}$ & 112 & $79.5-81.0$ & 1.858 & 0.994 \\
\hline
\end{tabular}

1 


\section{Table 3 (on next page)}

Expression stability of 10 candidate reference genes calculated by NormFinder. 


\begin{tabular}{|c|c|c|c|c|c|c|c|}
\hline Rank & Drought & Cold & Salt & ABA & GA & ETH & ALL \\
\hline 1 & $G A P C P 1$ & GAPCPI & GAPCP1 & $T U A 1$ & $T U A 1$ & GAPDH2 & GAPCP1 \\
\hline Stability & 0.025 & 0.015 & 0.089 & 0.071 & 0.075 & 0.048 & 0.028 \\
\hline 2 & $E F 1 B$ & $60 S$ & $T U A 1$ & $S A N D$ & CYP & $T U A 1$ & $60 S$ \\
\hline Stability & 0.052 & 0.018 & 0.089 & 0.072 & 0.075 & 0.051 & 0.031 \\
\hline 3 & $60 S$ & $E F 1 B$ & $S A N D$ & TUA6 & $G A P C P 1$ & $G A P C P 1$ & $C Y P$ \\
\hline Stability & 0.069 & 0.060 & 0.237 & 0.109 & 0.096 & 0.135 & 0.032 \\
\hline 4 & $S A N D$ & GAPDH2 & $60 S$ & $C Y P$ & $S A N D$ & $S A N D$ & $S A N D$ \\
\hline Stability & 0.074 & 0.076 & 0.284 & 0.159 & 0.103 & 0.149 & 0.065 \\
\hline 5 & $C Y P$ & $C Y P$ & $E F 1 B$ & $G A P C P 1$ & $60 S$ & $60 S$ & $T U A 1$ \\
\hline Stability & 0.245 & 0.238 & 0.319 & 0.188 & 0.323 & 0.150 & 0.130 \\
\hline 6 & TUA1 & $S A N D$ & $C Y P$ & $60 S$ & TUA6 & $M D H$ & $E F 1 B$ \\
\hline Stability & 0.316 & 0.385 & 0.371 & 0.201 & 0.358 & 0.207 & 0.163 \\
\hline 7 & TUA6 & TUA6 & $M D H$ & $M D H$ & GAPDH2 & $E F 1 B$ & $M D H$ \\
\hline Stability & 0.326 & 0.481 & 0.447 & 0.255 & 0.414 & 0.251 & 0.185 \\
\hline 8 & GAPDH 2 & $T U A 1$ & TUA6 & $E F 1 B$ & $E F 1 B$ & $C Y P$ & TUA6 \\
\hline Stability & 0.405 & 0.523 & 0.726 & 0.401 & 0.754 & 0.359 & 0.294 \\
\hline 9 & $M D H$ & $M D H$ & GAPDH2 & GAPDH2 & $M D H$ & $18 S$ & GAPDH 2 \\
\hline Stability & 0.615 & 0.586 & 1.286 & 0.516 & 0.836 & 0.486 & 0.357 \\
\hline 10 & $18 S$ & $18 S$ & $18 S$ & $18 S$ & $18 S$ & $T U 6$ & $18 S$ \\
\hline Stability & 0.999 & 1.093 & 1.748 & 1.272 & 0.965 & 0.497 & 0.556 \\
\hline
\end{tabular}

1 


\section{Table 4(on next page)}

Expression stability of 10 candidate reference genes calculated by BestKeeper. 


\begin{tabular}{llllllll}
\hline Rank & Drought & Cold & Salt & ABA & GA & ETH & ALL \\
\hline 1 & $T U A 1$ & $E F 1 B$ & $E F 1 B$ & $E F 1 B$ & $T U A 6$ & $G A P D H 2$ & $T U A 1$ \\
$\mathrm{CV} \pm \mathrm{SD}$ & $0.52 \pm 0.16$ & $1.16 \pm 0.31$ & $1.35 \pm 0.36$ & $1.04 \pm 0.27$ & $0.82 \pm 0.22$ & $0.68 \pm 0.18$ & $0.53 \pm 0.16$ \\
2 & $S A N D$ & $G A P C P 1$ & $G A P C P 1$ & $T U A 6$ & $60 S$ & $60 S$ & $E F 1 B$ \\
$\mathrm{CV} \pm \mathrm{SD}$ & $0.89 \pm 0.27$ & $1.21 \pm 0.37$ & $1.88 \pm 0.58$ & $1.06 \pm 0.29$ & $1.02 \pm 0.26$ & $1 \pm 0.26$ & $0.82 \pm 0.22$ \\
3 & $G A P D H 2$ & $T U A 1$ & $60 S$ & $60 S$ & $T U A 1$ & $T U A 1$ & $G A P C P 1$ \\
$\mathrm{CV} \pm \mathrm{SD}$ & $1.07 \pm 0.28$ & $1.39 \pm 0.41$ & $1.93 \pm 0.5$ & $1.27 \pm 0.32$ & $1.76 \pm 0.56$ & $1.16 \pm 0.35$ & $0.91 \pm 0.28$ \\
4 & $G A P C P 1$ & $60 S$ & $C Y P$ & $C Y P$ & $C Y P$ & $G A P C P 1$ & $60 S$ \\
$\mathrm{CV} \pm \mathrm{SD}$ & $1.24 \pm 0.38$ & $1.4 \pm 0.36$ & $2.1 \pm 0.61$ & $1.37 \pm 0.39$ & $1.78 \pm 0.52$ & $1.17 \pm 0.35$ & $0.93 \pm 0.24$ \\
5 & $E F 1 B$ & $G A P D H 2$ & $T U A 1$ & $S A N D$ & $S A N D$ & $M D H$ & $T U A 6$ \\
$\mathrm{CV} \pm \mathrm{SD}$ & $1.27 \pm 0.34$ & $1.48 \pm 0.38$ & $2.38 \pm 0.75$ & $1.45 \pm 0.43$ & $1.81 \pm 0.56$ & $1.2 \pm 0.33$ & $0.99 \pm 0.27$ \\
6 & $60 S$ & $C Y P$ & $S A N D$ & $G A P D H 2$ & $G A P D H 2$ & $S A N D$ & $S A N D$ \\
$\mathrm{CV} \pm \mathrm{SD}$ & $1.71 \pm 0.45$ & $1.77 \pm 0.52$ & $2.39 \pm 0.74$ & $1.76 \pm 0.45$ & $1.9 \pm 0.51$ & $1.21 \pm 0.36$ & $1.1 \pm 0.33$ \\
7 & $T U A 6$ & $T U A 6$ & $T U A 6$ & $M D H$ & $G A P C P 1$ & $E F 1 B$ & $C Y P$ \\
$\mathrm{CV} \pm \mathrm{SD}$ & $1.86 \pm 0.52$ & $1.87 \pm 0.49$ & $2.65 \pm 0.74$ & $1.92 \pm 0.53$ & $1.92 \pm 0.61$ & $1.43 \pm 0.37$ & $1.11 \pm 0.32$ \\
8 & $C Y P$ & $M D H$ & $M D H$ & $T U A 1$ & $E F 1 B$ & $T U A 6$ & $G A P D H 2$ \\
$\mathrm{CV} \pm \mathrm{SD}$ & $2.07 \pm 0.61$ & $2.06 \pm 0.57$ & $2.87 \pm 0.81$ & $1.95 \pm 0.58$ & $3.14 \pm 0.85$ & $1.61 \pm 0.44$ & $1.26 \pm 0.33$ \\
9 & $M D H$ & $S A N D$ & $G A P D H 2$ & $G A P C P 1$ & $M D H$ & $C Y P$ & $M D H$ \\
$\mathrm{CV} \pm \mathrm{SD}$ & $3.32 \pm 0.94$ & $2.31 \pm 0.7$ & $5.02 \pm 1.27$ & $2.07 \pm 0.63$ & $3.17 \pm 0.88$ & $1.62 \pm 0.46$ & $1.71 \pm 0.48$ \\
10 & $18 S$ & $18 S$ & $18 S$ & $18 S$ & $18 S$ & $18 S$ & $18 S$ \\
$\mathrm{CV} \pm \mathrm{SD}$ & $6.33 \pm 1.29$ & $8.32 \pm 1.63$ & $12.7 \pm 2.45$ & $8.26 \pm 1.46$ & $6.34 \pm 1.32$ & $2.91 \pm 0.52$ & $3.56 \pm 0.69$ \\
\hline & & & & & & &
\end{tabular}




\section{Table 5 (on next page)}

Expression stability ranking of the 10 candidate reference genes. 


\begin{tabular}{|c|c|c|c|c|c|c|c|c|c|c|}
\hline Method & 1 & 2 & 3 & 4 & 5 & 6 & 7 & 8 & 9 & 10 \\
\hline \multicolumn{11}{|c|}{ A. Ranking Order under drought stress (Better-Good-Average) } \\
\hline geNorm & \multicolumn{2}{|c|}{$G A P C P 1 / E F 1 B$} & $60 S$ & $S A N D$ & $T U A 1$ & $C Y P$ & $T U A 6$ & GAPDH2 & $M D H$ & $18 S$ \\
\hline Normfinder & GAPCP1 & $E F 1 B$ & $60 S$ & $S A N D$ & CYP & $T U A 1$ & TUA6 & GAPDH2 & $M D H$ & $18 S$ \\
\hline BestKeeper & $T U A 1$ & $S A N D$ & GAPDH2 & GAPCP1 & $E F 1 B$ & $60 S$ & TUA6 & $C Y P$ & $M D H$ & $18 S$ \\
\hline $\begin{array}{l}\text { Comprehensive } \\
\text { ranking }\end{array}$ & GAPCP1 & $E F 1 B$ & $S A N D$ & $T U A 1$ & $60 S$ & GAPDH2 & $C Y P$ & TUA6 & $M D H$ & $18 S$ \\
\hline \multicolumn{11}{|c|}{ B. Ranking Order under cold stress (Better-Good-Average) } \\
\hline geNorm & \multicolumn{2}{|c|}{ GAPCP1/60S } & $E F 1 B$ & $G A P D H 2$ & $C Y P$ & $S A N D$ & TUA6 & $T U A 1$ & $M D H$ & $18 S$ \\
\hline Normfinder & GAPCP1 & $60 S$ & $E F 1 B$ & GAPDH 2 & CYP & SAND & TUA6 & $T U A 1$ & $M D H$ & $18 S$ \\
\hline BestKeeper & $E F 1 B$ & $G A P C P 1$ & TUA1 & $60 S$ & GAPDH2 & $C Y P$ & TUA6 & $M D H$ & $S A N D$ & $18 S$ \\
\hline $\begin{array}{l}\text { Comprehensive } \\
\text { ranking }\end{array}$ & GAPCP1 & $E F 1 B$ & $60 S$ & GAPDH2 & $C Y P$ & $T U A 1$ & $S A N D$ & TUA6 & $M D H$ & $18 S$ \\
\hline \multicolumn{11}{|c|}{ C. Ranking Order under salt stress (Better-Good-Average) } \\
\hline geNorm & $E F 1 B / 60 S$ & & CYP & $G A P C P 1$ & TUA1 & SAND & $M D H$ & TUA6 & GAPDH 2 & $18 S$ \\
\hline Normfinder & GAPCP1 & $T U A 1$ & $S A N D$ & $60 S$ & $E F 1 B$ & CYP & $M D H$ & $T U A 6$ & $G A P D H 2$ & $18 S$ \\
\hline BestKeeper & $E F 1 B$ & GAPCP1 & $60 S$ & $C Y P$ & TUA1 & SAND & TUA6 & $M D H$ & GAPDH2 & $18 S$ \\
\hline $\begin{array}{l}\text { Comprehensive } \\
\text { ranking }\end{array}$ & $E F 1 B$ & GAPCP1 & $60 S$ & TUA1 & $C Y P$ & $S A N D$ & $M D H$ & TUA6 & GAPDH2 & $18 S$ \\
\hline \multicolumn{11}{|c|}{ D. Ranking Order under ABA treatment (Better-Good-Average) } \\
\hline geNorm & \multicolumn{2}{|c|}{ MON 1/TUA 6} & CYP & $60 S$ & $T U A 1$ & $M D H$ & $G A P C P 1$ & $E F 1 B$ & GAPDH2 & $18 S$ \\
\hline Normfinder & $T U A 1$ & $S A N D$ & TUA6 & $C Y P$ & $G A P C P 1$ & $60 S$ & $M D H$ & $E F 1 B$ & GAPDH2 & $18 S$ \\
\hline BestKeeper & $E F 1 B$ & TUA6 & $60 S$ & $C Y P$ & $S A N D$ & GAPDH2 & $M D H$ & TUA1 & GAPCP1 & $18 S$ \\
\hline $\begin{array}{l}\text { Comprehensive } \\
\text { ranking }\end{array}$ & TUA6 & $S A N D$ & $C Y P$ & $T U A 1$ & $60 S$ & $E F 1 B$ & $M D H$ & $G A P C P 1$ & GAPDH2 & $18 S$ \\
\hline \multicolumn{11}{|c|}{ E. Ranking Order under GA treatment (Better-Good-Average) } \\
\hline geNorm & \multicolumn{2}{|c|}{$T U A 1 / C Y P$} & $G A P C P 1$ & $S A N D$ & $60 S$ & TUA6 & GAPDH2 & $E F 1 B$ & $M D H$ & $18 S$ \\
\hline Normfinder & $T U A 1$ & CYP & $G A P C P 1$ & $S A N D$ & $60 S$ & TUA6 & GAPDH 2 & $E F 1 B$ & $M D H$ & $18 S$ \\
\hline BestKeeper & TUA6 & $60 S$ & $T U A 1$ & $C Y P$ & $S A N D$ & GAPDH2 & $G A P C P 1$ & $E F 1 B$ & $M D H$ & $18 S$ \\
\hline $\begin{array}{l}\text { Comprehensive } \\
\text { ranking }\end{array}$ & $T U A 1$ & $C Y P$ & TUA6 & $G A P C P 1$ & $60 S$ & $S A N D$ & GAPDH 2 & $E F 1 B$ & $M D H$ & $18 S$ \\
\hline \multicolumn{11}{|c|}{ F. Ranking Order under ETH treatment (Better-Good-Average) } \\
\hline geNorm & \multicolumn{2}{|c|}{ GAPDH2/60S } & TUAI & SAND & GAPCP1 & $M D H$ & $E F 1 B$ & $C Y P$ & $18 S$ & TUA6 \\
\hline Normfinder & GAPDH 2 & $T U A 1$ & $G A P C P 1$ & $S A N D$ & $60 S$ & $M D H$ & $E F 1 B$ & CYP & $18 S$ & TUAO \\
\hline BestKeeper & GAPDH 2 & $60 S$ & $T U A 1$ & $G A P C P 1$ & $M D H$ & SAND & $E F 1 B$ & TUA6 & $C Y P$ & $18 S$ \\
\hline $\begin{array}{l}\text { Comprehensive } \\
\text { ranking }\end{array}$ & GAPDH2 & $60 S$ & $T U A 1$ & $G A P C P 1$ & $S A N D$ & $M D H$ & $E F 1 B$ & CYP & TUA6 & $18 S$ \\
\hline \multicolumn{11}{|c|}{ H. Ranking Order under ALL stress (Better-Good-Average) } \\
\hline geNorm & \multicolumn{2}{|c|}{ GAPCP $1 / C Y P$} & $60 S$ & $T U A 1$ & $E F 1 B$ & $S A N D$ & $M D H$ & $T U A 6$ & GAPDH2 & $18 S$ \\
\hline Normfinder & $G A P C P 1$ & $60 S$ & CYP & $S A N D$ & $T U A 1$ & $E F 1 B$ & $M D H$ & TUA6 & GAPDH2 & $18 S$ \\
\hline BestKeeper & $T U A 1$ & $E F 1 B$ & $G A P C P 1$ & $60 S$ & TUA6 & $S A N D$ & $C Y P$ & GAPDH 2 & $M D H$ & $18 S$ \\
\hline $\begin{array}{l}\text { Comprehensive } \\
\text { ranking }\end{array}$ & GAPCP1 & $60 S$ & TUA1 & $C Y P$ & $E F 1 B$ & $S A N D$ & TUA6 & $M D H$ & GAPDH2 & $18 S$ \\
\hline
\end{tabular}


Figure 1

Distribution of $\mathrm{Ct}$ values for ten candidate RGs across all S. chamaejasme samples.

Lines across the boxes denote the medians. The box represents the 25th and 75th percentile.

The top and bottom whisker caps depict the maximum and minimum values, respectively.

The white and black dots represent mean Ct values and potential outliers, respectively.

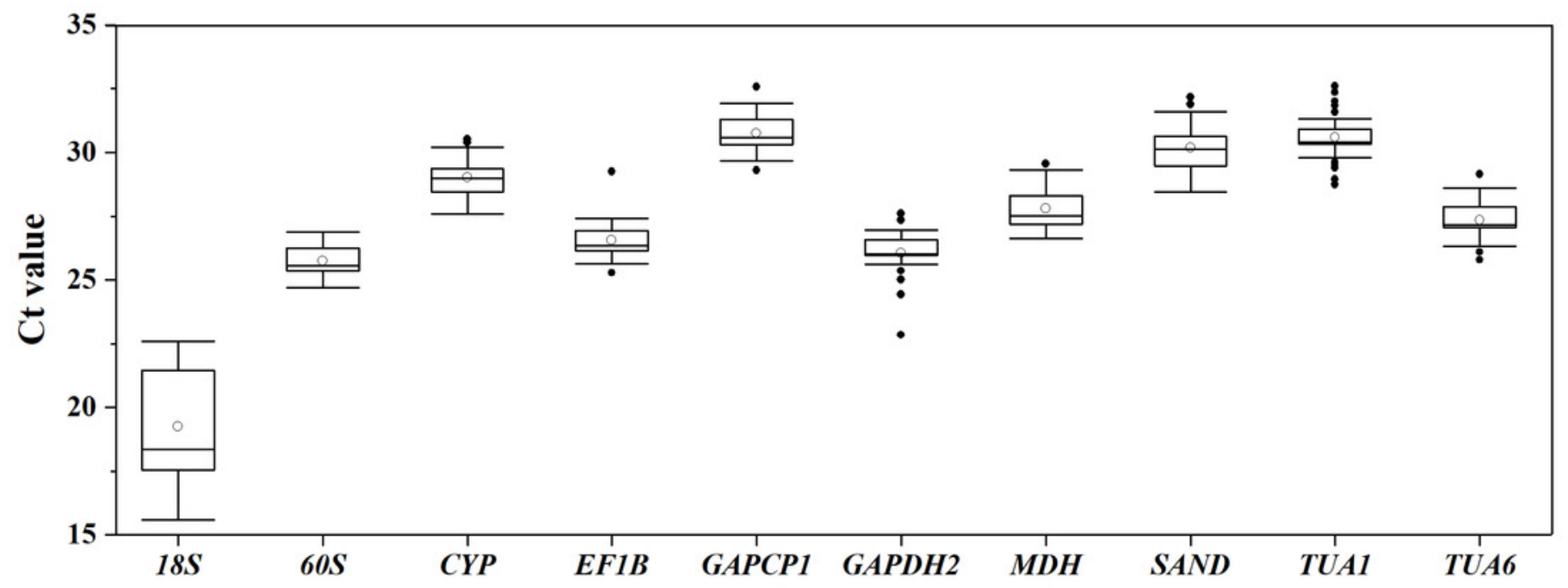


Figure 2

Average expression stability value $(\mathrm{M})$ and ranking of the ten RGs across all treatments calculated using geNorm.

The least stable genes are listed on the left, while the most stable genes are exhibited on the right.

$\mathbf{A}$

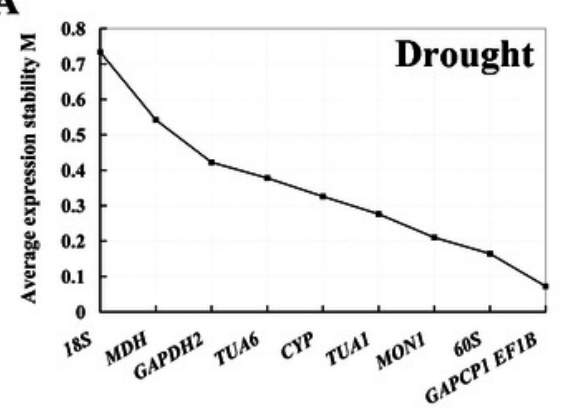

D

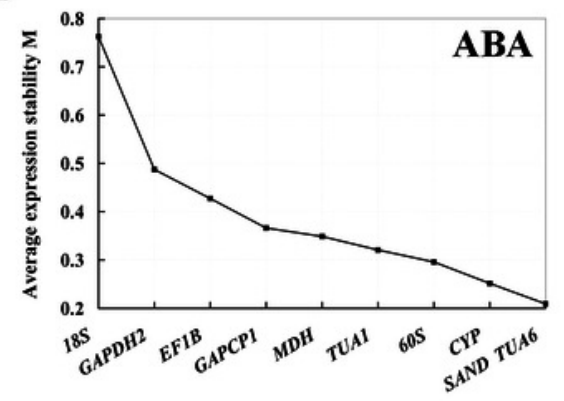

G

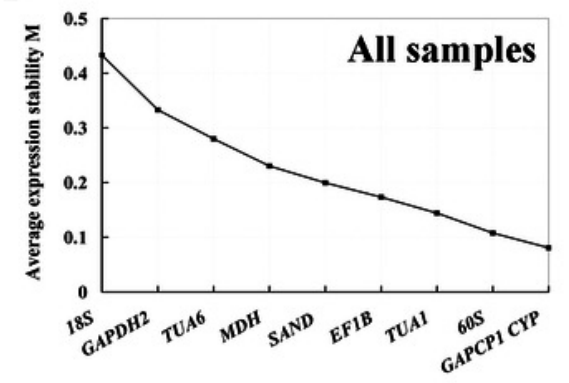

B

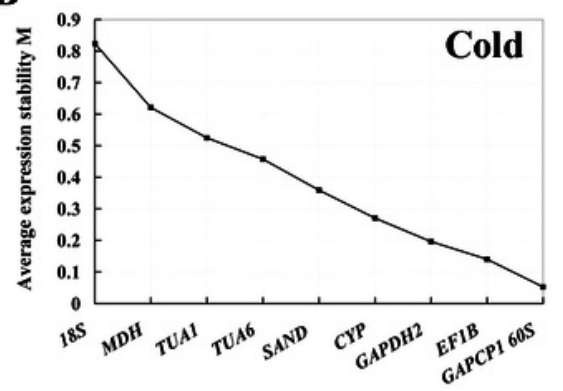

$\mathbf{E}$

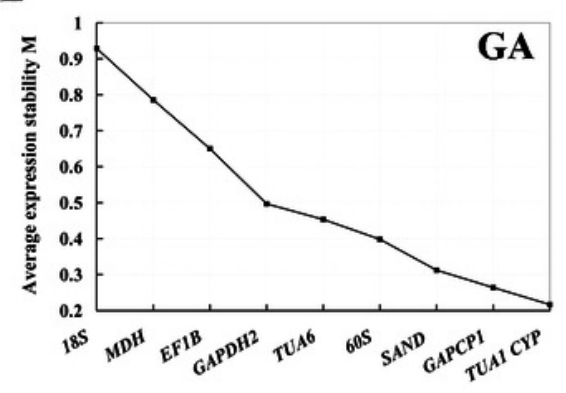

C

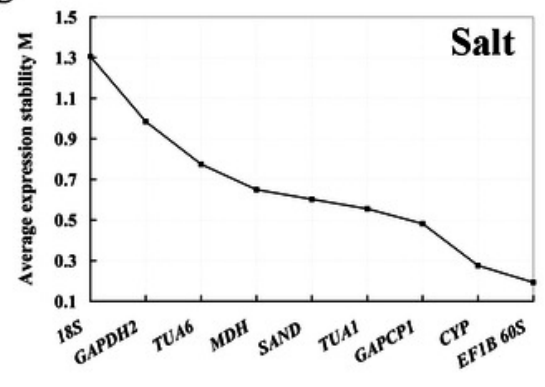

F

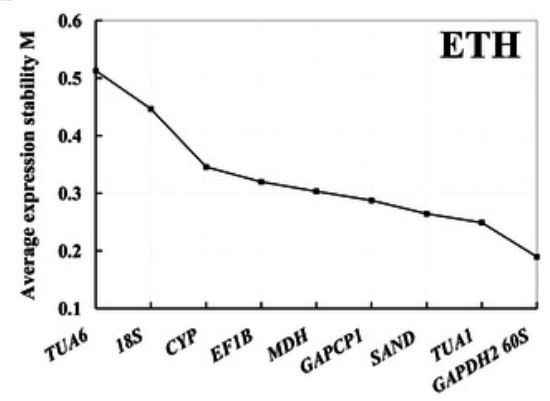


Figure 3

Pairwise variation $(\mathrm{Vn} / \mathrm{Vn}+1)$ values analysis in all the seven experimental subsets calculated using geNorm.

The cut-off value to determine the optimal number of RGs for qRT-PCR normalization is 0.15 .

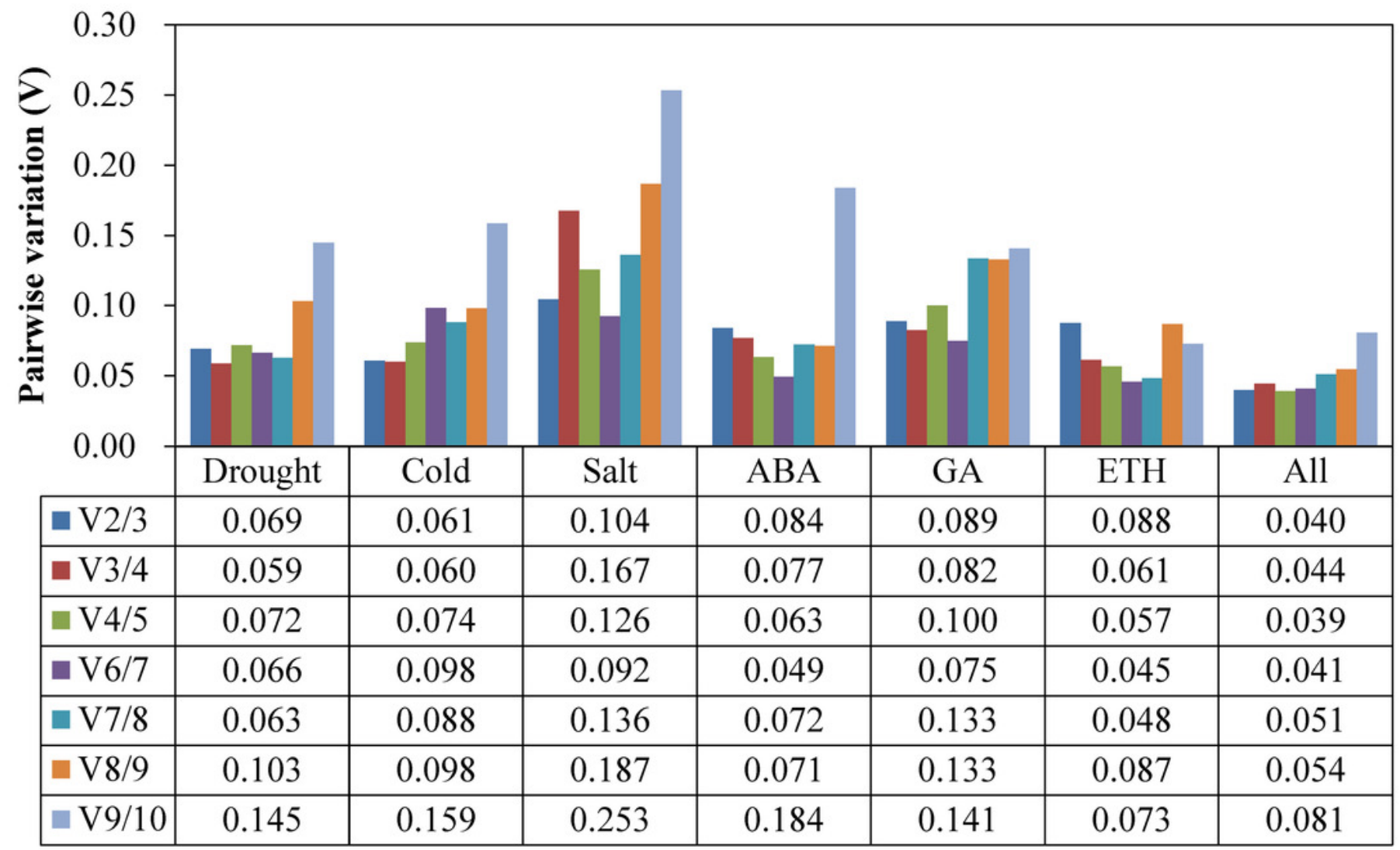


Figure 4

Comprehensive ranking of candidate genes calculated by the geometric mean of three types of rankings (geNorm, NormFinder, and BestKeeper) in each subset.

A

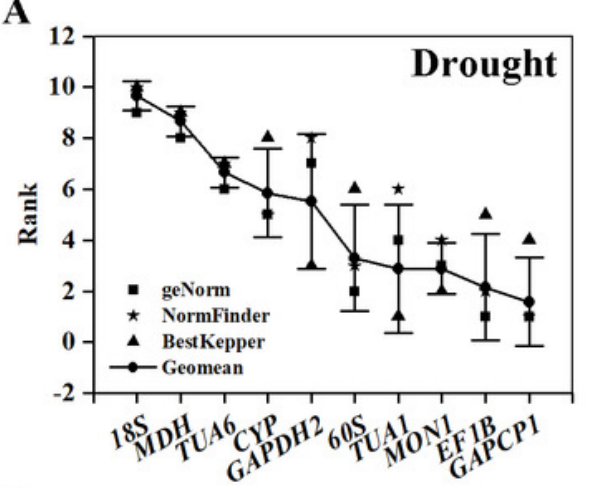

D

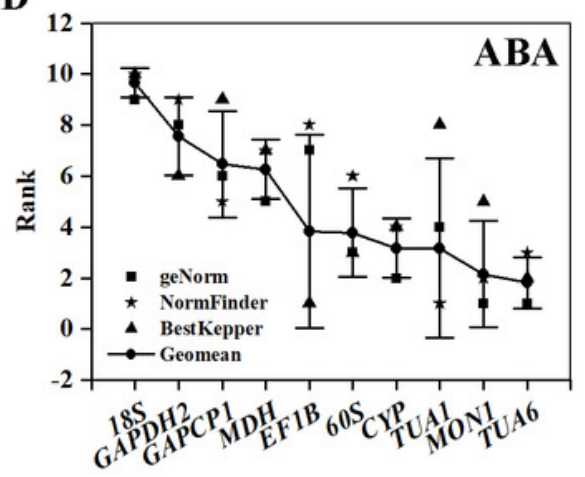

G

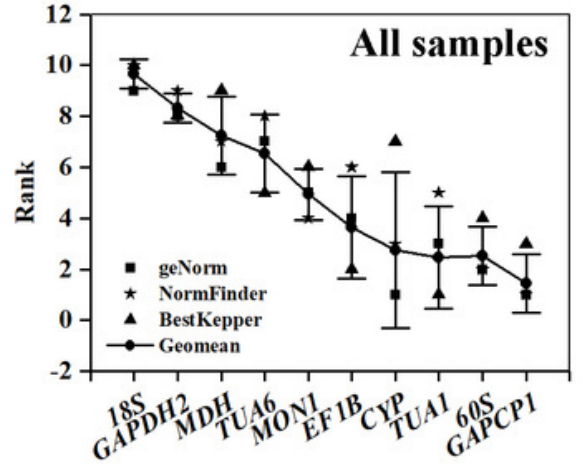

B

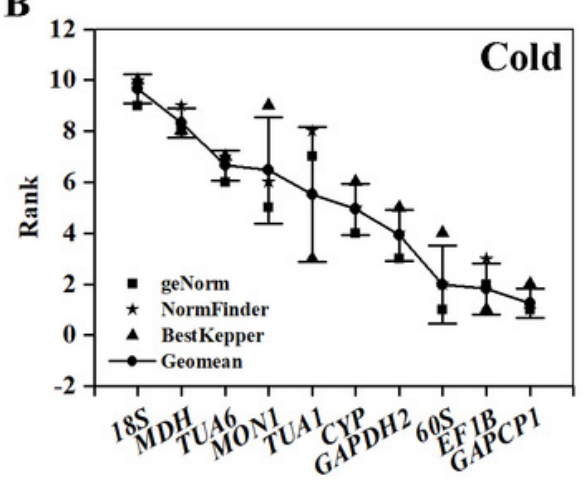

$\mathbf{E}$

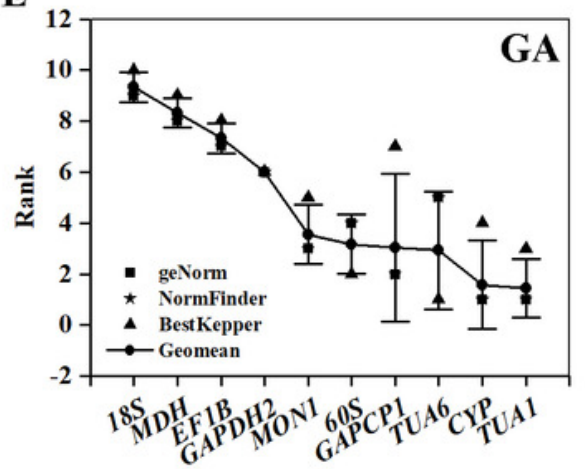

C

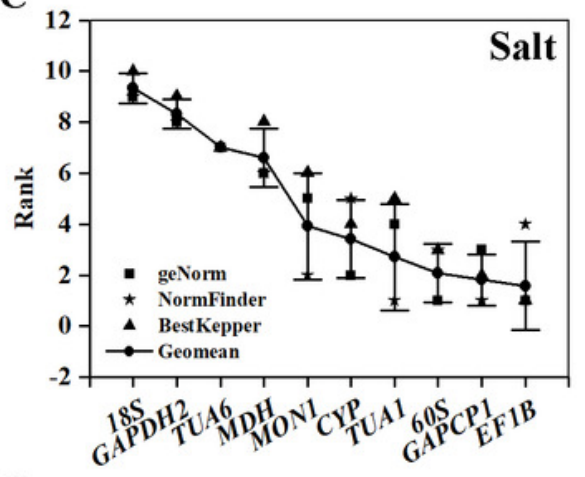

F

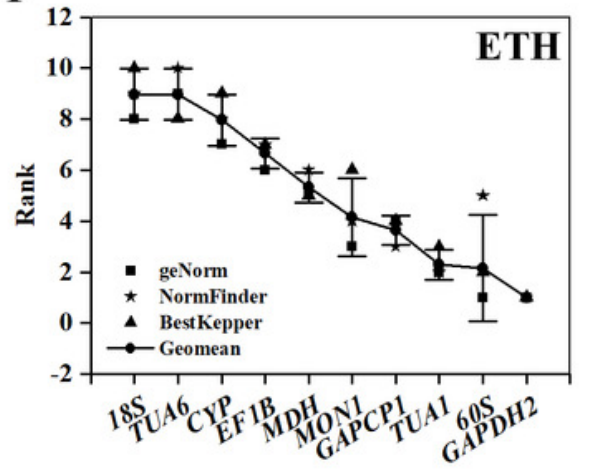


Figure 5

Relative expression levels of P5CS2 under different experimental conditions normalized by the most stable RG combination, the most stable gene and the most unstable gene.

(A) Drought stress. (B) Cold stress. (C) Salt stress. (D) ABA treatment. (E) GA treatment. (F) ETH treatment. Bars represent the standard error from three biological replicates.
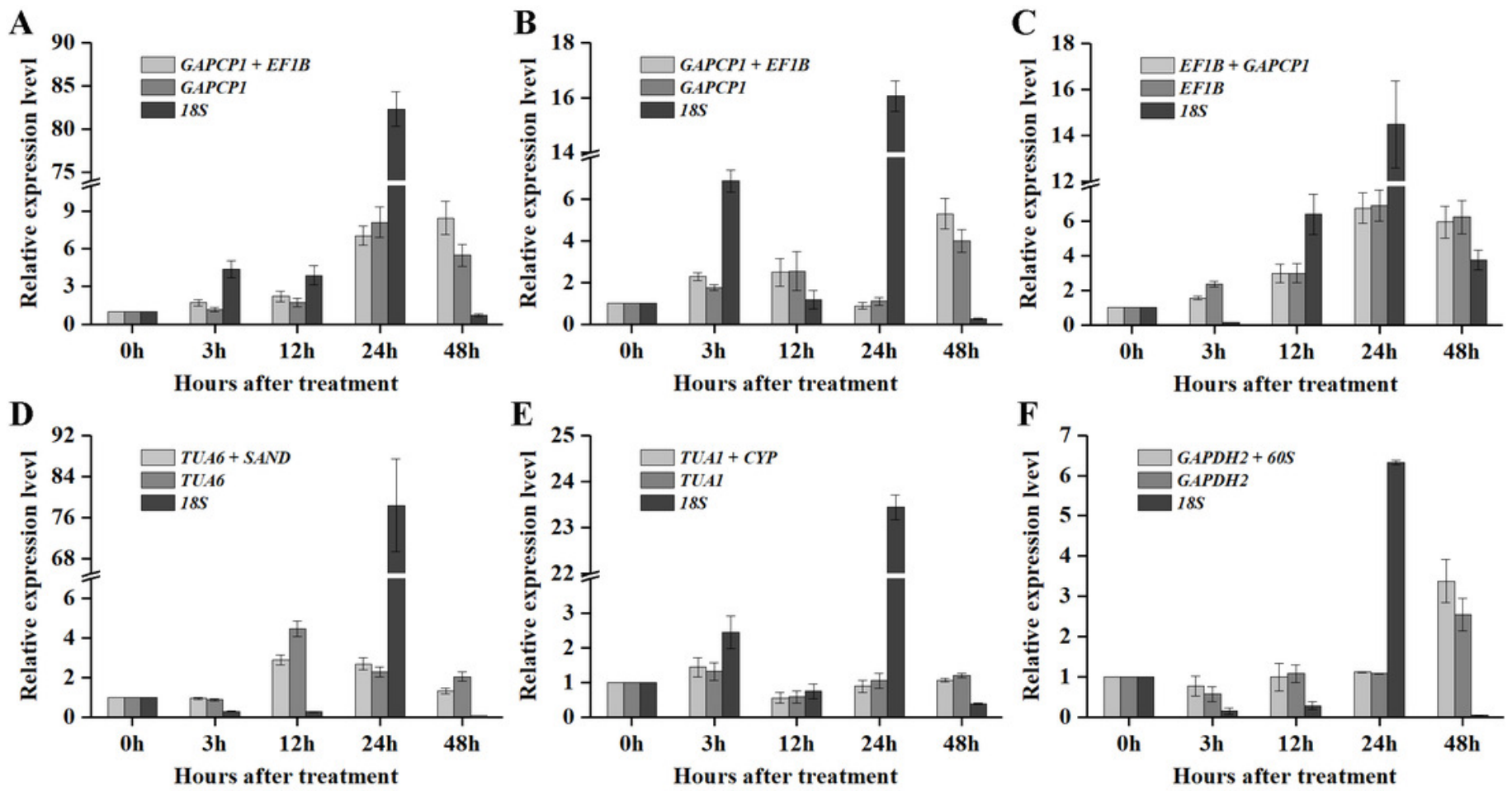
Figure 6

Relative expression levels of $G /$ under different experimental conditions normalized by the most stable RG combination, the most stable gene and the most unstable gene.

(A) Drought stress. (B) Cold stress. (C) Salt stress. (D) ABA treatment. (E) GA treatment. (F) ETH treatment. Bars represent the standard error from three biological replicates.
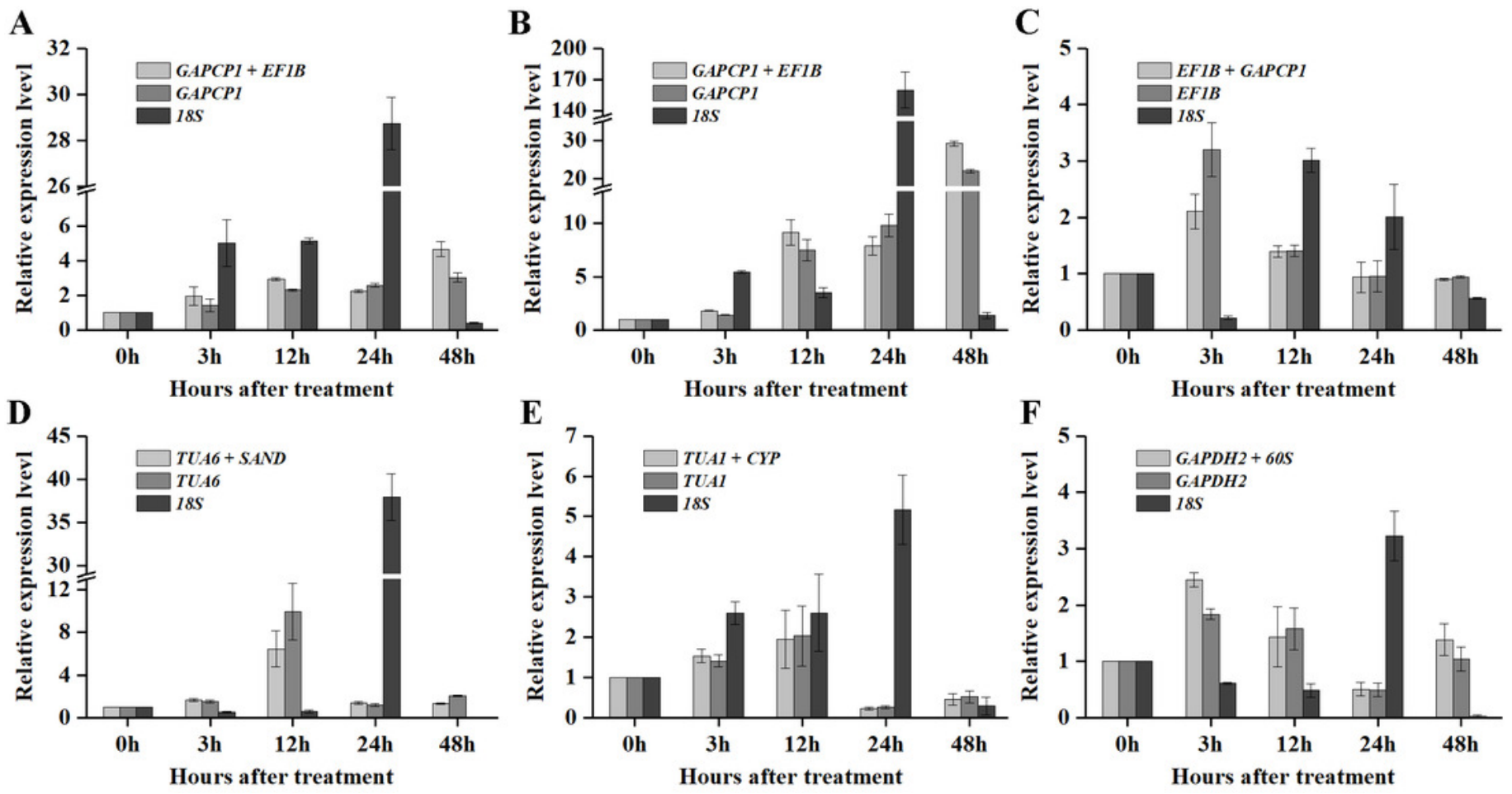